\title{
Development of African History-Based Multiculturalism for Historical Education Students
}

\author{
Abdul Haris Nasution, Flores Tanjung, Arfan Diansyah \\ \{abdharisnasution@unimed.ac.id, arfandiansyahhutagaol@gmail.com, flores_tanjung@yahoo.co.id\}
}

Universitas Negeri Medan, North Sumatera, Indonesia ${ }^{1,2,3}$

\begin{abstract}
The purpose of this research is to develop African history teaching materials based on multiculturalism for historical education students. Data collection is done using polls, observations, and interviews. The teaching materials are developed using the Borg and Gall models grouped in four stages, namely preliminary study, development, field test, dissemination and dissemination of products. Assessment of the 4.14 material members included in the good category and the assessment of the 4.07 media experts included in the good criteria. Student assessments in limited field test stages, wider field tests, and operational tests of 4.19 respectively; 4.26; and 4.14. The value 4.19 in field trials are included in the good criteria, the value of 4.26 in the broader field test is included in excellent criteria, and the value 4.14 in the operational test is included in the good criteria.
\end{abstract}

Keywords: Teaching materials, African history, multiculturalism

\section{Introduction}

Teaching materials are a basic thing that every teacher especially lecturer. Therefore, each lecturer needs to implement the development of cutting-edge materials under its student characteristics. This is in line with the opinion of (Hamid Hasan, 2017) at the 2017 APPS Seminar, that the most up-to-date teaching materials are the results of the lecturer's research. The development of teaching materials is implemented as a way to identify, develop, and evaluate learning content and strategies. Besides, the development of teaching materials considers the nature of teaching materials, the number of students, and material availability. The principle of supply means it can accept new things that are not covered by the substance of the course at the time of its implementation(Mbulu Joseph, 2001). The principle of supply means students can receive new values/competencies in courses through lectures delivered by the lecturer. These competencies can be realized through the learning process that has been set through a semester learning Implementation plan (RPS).

In this study, researchers will develop the materials of African history which are based on the values of multiculturalism in the study of African history in the Department of History Education of FIS UNIMED. It is based on the lack of the availability of literature on African history. As for the literature circulating the market is only literature-a Grand Narrative, which is the poor value (valueless) and tends to contain narratives about causation. Whereas the content of African history material is very full of the values of the potential multiculturalism to be internalized in students, especially amid the establishment of SARA issues and ethnicity today. 
The African history lecture material is full of the values of multiculturalism. Multiculturalism is a value manifested by the accepting, respecting and open behaviors of cultural differences, behaviors, and beliefs of the cross-ethnic community (Banks, 1961). Internalizing the values of multiculturalism can prevent the integration of the nation from the smallest conflicts, such as fading stereotype-stereotypes of specific skin cultures and colors. Therefore, the value is very urgent to be developed through learning activities.

The course of African history contains materials about the origins of human ancestors, the world's great civilizations to the role of Africans in international world politics. These materials are supported by the results of new research and theories, such as the Out of Africa theory that reinforces the evidence that all human beings on Earth are migrating from previous African humans. This theory is reinforced by the DNA testing conducted by the Eijkman Institute of Forensic DNA identification Unit team, which finds the similarity of DNA among Indonesian humans and humans from mainland Asia and Africa. The results of the cultural studies conducted by the Archaeological Hall of North Sumatra also convey the similarity of human culture that originated from Asia-Africa.

The results of the study are certainly very relevant if developed into the form of teaching the history of African-based multiculturalism, to instill the spirit of multiculturalism and diversity ranging from the smallest sphere, the class to the community. Therefore, the study of African history teaching materials-based multiculturalism for historical education students is very important to do.

\section{Methods}

The method used in this research is a research and development method. The development research method is a method used to produce a specific product and to test the effectiveness of the product (Sugiyono, 2010). Research and development is a process or stepby-step to develop a product or to improve existing products, which can be accounted for. The process of developing materials of Africa-based history of multiculturalism uses the research and development model (R\&D) by Borg and Gall (Sugiono,2010). The design stage of the teaching materials product, including the selection of teaching materials, and initial planning; stage of production/implementation of initial product development, covering the manufacture of teaching materials, and drafting of assessment instruments, validation phase, covering assessment from design experts (history education lecturer), and assessment of the material experts (history education lecturer), the revision phase, including revisions or improvements to the media based on suggestions by the validators, the test phase of the product, including the student's material test, the student's poll and the implementation of the study results test; and phase of final revision and dissemination, including analysis of the success of media and the repair or final revision on the media as well as media dissemination. This research is only carried out until the trial stage.

\section{Result and discussion}

Preliminary study results in class B regular 2018 showed that the most common learning methods conducted by lecturers are using conventional methods so that the students get bored quickly. Besides, the use of learning resources is limited to narrative grand literature. The 
presentation of material in Grand narrative literature is judged still not able to lift the student motivation because the presentation of material passing language of long causality less liked by students. Students tend to like teaching books that contain contemporary materials, which are full of contextual dimensions and can be internalized in attitude form.

The materials in the African History of study are the material that students are less interested in. Students consider this material to contain many memorizations and not contextual elements, and the material to be learned is quite a lot. One of the subjects that are considered difficult by the students is about the origins Of the African nation and the theory Of Out Of Africa. In the subject, there are quite a lot of important events and important dates that students should memorize. Due to the many materials that must be memorized, students become lazy to learn the material. Students still often struggle to achieve value in these materials. According to lecturers, the achievement of student value for the material is also still not satisfactory.

The problems in learning for the material of African origins and the Out of Africa theory can be solved when the material is presented in an interesting and contemporary form. The presentation of interesting and contemporary material can give a feeling of delight in students to learn so that the delivery of materials and planting value can run the maximum. It is under the opinions of Peter Kline (Su'ud, 2007) stating that learning will be effective when done in a fun and enjoy. When students have a high interest in learning, the teaching materials will be more easily absorbed by the students.

Product development is conducted by analyzing the objectives in the development of African history teaching materials products based on multiculturalism, analysis of capabilities, implementing development procedures as well as conducting expert validation. The goal that is intended to be achieved in the development of this teaching material is to produce a product of African history-based multiculturalism which is worthy of material study Of African origins and the Out Of Africa theory. Developed teaching materials products are expected to improve motivation and help students learn.

Material development is the product of teaching materials extracted from various sources is then summarized in a product. The presentation of material in the teaching material is arranged in a text narrative that is charged with the values of multiculturalism. The next step after the preparation of teaching materials is the validation of products by the material experts and media experts who are experienced in their field. Material assessment refers to the aspect of consideration of the content consisting of the conformity of curriculum, appropriateness, and way of happiness. The aspect of the assessment refers to the opinion of Hartono Kasmadi (Suprayogi, 2007) stating that one of the things to consider in the development of teaching materials is the consideration of content.

Meanwhile, media-faceted assessments include aspects of production criteria, visual design, and technical quality. The aspect of the assessment refers to the opinion of Hartono (Suprayogi, 2007) stating that in the selection and development of media aspects that need to be considered include the consideration of production, learners, content, and lecturers. The assessed aspects of the visual design include the manifest visual elements of the Spiritual (1997:20-25) i.e. simplicity, alignment, emphasis, balance, line, shape, space, texture, and color. In other opinion (Tatalovic, 2009) said that the selection of media should pay attention to media suitability with the purpose of learning, the suitability of media with learner characteristics, media suitability with Learning environment, ease and implementation of media utilization, can be a source of learning, media efficiency in relation to the time, energy and cost, safety for learners, the ability of media in activating students, the ability of media in Develop a pleasant learning atmosphere, as well as media quality. Assessment of technical 
quality aspect includes media ability to motivate students, facilitate students remembering materials, media presentation makes the material more interesting as well as media ease of use.

Based on the results of the data analysis on the validation results of material experts conducted in two phases with a single revision, the average score is 3.95 on the first stage and 4.14 assessment of the second stage. The average scoring of the material members acquired by the developed teaching materials product is included in the "good" criteria according to quantitative data conversion guidelines to qualitative data(Uno, 2008). Under the research provisions that the teaching materials products are said to be feasible if the average minimum score includes good criteria, the developed teaching materials are worthy of the material content. The feasibility of the teaching material is supported by the expert stated that the product of teaching materials has been tested in terms of material.

The material expert assessment is based on the material content consideration criteria. The content considerations consist of a curriculum conformity indicator, the correctness of content, and the presentation way. If further analyzed, the material expert assessment score is spelled out in the following table.

Table 1. Expert assessment results for individual criteria

\begin{tabular}{ccc}
\hline Criteria & Number of grains & Average \\
\hline Content considerations & 22 & 4,00 \\
\hline
\end{tabular}

Table 2. Analysis of expert assessment results per-indicator

\begin{tabular}{ccccc}
\hline criteria & indicator & $\begin{array}{c}\text { number of } \\
\text { grains }\end{array}$ & number & average \\
\hline $\begin{array}{c}\text { Content } \\
\text { consideration }\end{array}$ & $\begin{array}{c}\text { Conformity } \\
\text { Curriculum }\end{array}$ & 3 & $1,2,3$ & 4,00 \\
& $\begin{array}{c}\text { Truth of Contents } \\
\text { Way Serving }\end{array}$ & 5 & $4,5,6,7,8$ & 4,00 \\
& & & $9,10,11,12,13$, & 4,21 \\
& & & $14,15,16,17,18,19$, & \\
& & Average & $20,21,22$ & 4,14 \\
\hline
\end{tabular}

The developed teaching materials products are under the curriculum, the learning indicators taken. The developed teaching materials have been well-seen from the curriculum conformity indicator with an average score of 4.00. Judging from the content truth indicator, the material in the comic media is already good with an average score of 4.00 . The correctness of the content includes the chronology, value-and-role content of the characters in the teaching materials product media is good.

It is further seen for the indicator how the material is presenting, with an average acquisition score of 4.21 indicating that the teaching material is very good. Developed materials products can present more concrete material, presentation of the material can help students understand the material, help students remember the material, the content of the value of multiculturalism is according to the indicator. 
While the validation of media experts is done in three phases, with two revisions. The average score obtained consecutively $2.82,3.80$, and 4.07 . The average score gained on the first stage assessment according to quantitative data conversion guidelines to qualitative (Olson, 2007) is included in "insufficient" criteria. While the average score gained on the assessment of the second and third stages is included in the category "good". According to the terms of research that the product of teaching materials is said to be feasible if the average score is minimal including good criteria, then the developed teaching materials have been appropriate in terms of media considerations. The assessment of media experts is based on production criteria, visual design, and technical quality. Each criterion is seen from various indicators. Further analysis of the material expert validation result assessment can be seen in the following table.

Table 3. Media Expert assessment results for individual criteria

\begin{tabular}{ccc}
\hline Criteria & $\begin{array}{c}\text { Numbers of } \\
\text { gains }\end{array}$ & Average \\
\hline Production criteria & 8 & 4,12 \\
Visual Design & 16 & 4,00 \\
Technical quality & 4 & 4,20 \\
\hline
\end{tabular}

Table 4. Per-Indicator Media expert assessment results analysis

\begin{tabular}{|c|c|c|c|c|}
\hline criteria & indicator & $\begin{array}{c}\text { number of } \\
\text { grains }\end{array}$ & number & average \\
\hline \multirow{2}{*}{$\begin{array}{l}\text { production } \\
\text { criteria }\end{array}$} & physical condition & 2 & 1,2 & 4,00 \\
\hline & quality of materials & 4 & $3,4,5,6$ & 4,00 \\
\hline \multirow[t]{4}{*}{ visual design } & $\begin{array}{c}\text { emotion impact } \\
\text { visual principles of } \\
\text { cover design }\end{array}$ & $\begin{array}{l}2 \\
4\end{array}$ & $\begin{array}{c}7,8 \\
9,10,11,12\end{array}$ & $\begin{array}{l}4,50 \\
4,00\end{array}$ \\
\hline & $\begin{array}{l}\text { visual principles of } \\
\text { story content } \\
\text { illustration }\end{array}$ & 4 & $13,14,15,16$ & 4,00 \\
\hline & $\begin{array}{l}\text { visual principles of } \\
\text { historical summaries }\end{array}$ & 4 & $17,18,19,20$ & 4,00 \\
\hline & $\begin{array}{l}\text { visual principle of } \\
\text { illustration of } \\
\text { historical figures }\end{array}$ & 4 & $21,22,23,24$ & 4,00 \\
\hline $\begin{array}{l}\text { technical } \\
\text { quality }\end{array}$ & $\begin{array}{l}\text { good media } \\
\text { requirements }\end{array}$ & 4 & $25,26,27,28$ & 4,20 \\
\hline \multicolumn{4}{|c|}{ total average } & 4,07 \\
\hline
\end{tabular}

Generally based on production criteria (item valuation number 1-8) developed teaching materials obtain an average score of 4.12 including the good category. The physical condition of the teaching material was good with an average score of 4.00. Physical conditions are assessed from the aspect of size and shape and practicality of the teaching materials. The quality of the teaching materials is good with an average score of 4.00. The aspects assessed in the material quality indicator consist of the ease of material acquired, material safety, print 
quality, as well as durability of materials. Furthermore, the emotional impact of the teaching product is gaining an average score of 4.50 which means it is already very good. The developed teaching materials contain aesthetic value and can make student learning more enjoyable.

Based on the visual design criteria (item valuation number 9-24), the developed teaching materials product has fulfilled the principles of visual design with a score of 4.00. The principal indicator of the cover's visual design, material content or the value of multiculturalism earns an average score of 4.00 which is included in good criteria. The visual design principles assessed include an assessment of the layout, color choices, image suitability, and font type and size.

Furthermore, technically quality with a good indicator of teaching materials requirements, teaching materials products include good criteria with an acquisition score of 4.20. Assessment of good teaching materials requirements includes the ability to motivate students, facilitate students to remember, make a presentation of interesting materials and effectiveness in the process of internalization of value.

The teaching materials products that have received a decent recommendation from material experts or media experts are already qualified to be tested in the field. The average earning score on the field test stage is limited, the field test is wider and the operational test in a row of 4.19, 4.26 and 4.14 with good, excellent, and good categories. The results of the Student Assessment score analysis for each criterion and indicators are outlined in the table below.

Table 5. Field test assessment results for individual criteria

\begin{tabular}{ccccc}
\hline Criteria & $\begin{array}{c}\text { Number of } \\
\text { grains }\end{array}$ & Limited & Average score Field test \\
& 8 & 4,28 & 4,17 & 4,11 \\
\hline $\begin{array}{c}\text { Terms of material } \\
\text { presentation }\end{array}$ & 8 & 4,14 & 4,31 & 4,15 \\
\hline
\end{tabular}

Table 6. Analysis of student Assessment results in field tests per-indicator

\begin{tabular}{|c|c|c|c|c|c|c|}
\hline \multirow[t]{2}{*}{ Criteria } & \multirow[t]{2}{*}{ Indicator } & \multirow{2}{*}{$\begin{array}{l}\text { Number } \\
\text { of grains }\end{array}$} & \multirow[t]{2}{*}{ Number } & \multicolumn{3}{|c|}{ Average score Field test } \\
\hline & & & & Limited & $\begin{array}{l}\text { More } \\
\text { space }\end{array}$ & Operational \\
\hline \multirow{5}{*}{$\begin{array}{c}\text { Terms of } \\
\text { material } \\
\text { presentation }\end{array}$} & Material interest & 2 & 1,2 & 4,33 & 4,08 & 3,97 \\
\hline & Student Benefits & 1 & 3 & 4,00 & 4,17 & 4,16 \\
\hline & Contextual & 1 & 4 & 3,67 & 4,50 & 4,21 \\
\hline & $\begin{array}{l}\text { Material } \\
\text { Summary }\end{array}$ & 1 & 5 & 5,00 & 4,17 & 4,26 \\
\hline & Language use & 1 & 6 & 4,33 & 4,00 & 4,11 \\
\hline \multirow{4}{*}{$\begin{array}{c}\text { Terms of } \\
\text { Media } \\
\text { presentation }\end{array}$} & Shape and size & 2 & 7,8 & 4,16 & 4,25 & 3,94 \\
\hline & Ease of Use & 1 & 9 & 4,33 & 4,67 & 4,16 \\
\hline & Color options & 1 & 10 & 4,33 & 4,17 & 4,37 \\
\hline & Use of letters & 1 & 11 & 3,67 & 4,33 & 4,32 \\
\hline
\end{tabular}




\begin{tabular}{lccccc} 
Image & 1 & 12 & 3,67 & 4,50 & 4,11 \\
$\begin{array}{c}\text { illustration } \\
\begin{array}{c}\text { Content of } \\
\text { material }\end{array}\end{array}$ & 2 & 13,14 & 3,67 & 4,00 & 4,16 \\
$\begin{array}{c}\text { Media uses } \\
\text { Technical }\end{array}$ & 3 & $15,16,17$ & 4,44 & 4,22 & 4,14 \\
$\begin{array}{c}\text { quality } \\
\text { Total Average }\end{array}$ & 1 & 18 & 4,33 & 4,83 & 4,26 \\
\hline
\end{tabular}

The student assessment results for the material presentation (Student Valuation Item number 1-6) on the limited test received an average score of 4.28 means the presentation of the material in the teaching materials developed very well. The indicators assessed include teaching materials, benefits for students, contextual materials, material summaries and the use of languages with a score of $4.33 ; 4.00 ; 3.67 ; 5.00$; and 4.33 . Meanwhile, for the presentation of teaching materials (Student Valuation Item number 7-18), the average score of 4.14 means that the teaching materials are already well developed. The scoring indicators include shape and size, ease of use, color choice, use of letters, image illustrations, the material content of materials, teaching materials, and technical qualities with a score of each $4.16 ; 4.33 ; 4.33$; $3.67 ; 3.67 ; 3.67 ; 4.44$; and 4.33 .

Student Assessment results for material presentation (Student Valuation Item number 1-6) on the broad Test received an average score of 4.17 means that the teaching materials developed are good. Indicators assessed include teaching materials, benefits for students, contextual material, material summaries and language usage with a score of 4.08 respectively; 4.17; 4.50; 4.17; and 4.00. Meanwhile, for the presentation of teaching materials (Student Valuation Item number 7-18), the score of 4.31 means that developed teaching materials product is very good. The scoring indicators include shape and size, ease of use, color choice, use of letters, image illustrations, material content, teaching materials, and the quality of the techniques with a score of each $4.25 ; 4.67 ; 4.17 ; 4.33 ; 4.50 ; 4.00 ; 4.22$; and 4.83 .

The student assessment results in the course of presentation (item No. 1-6) on the operational test obtaining an average score of 4.11 means that the teaching materials developed are good. Indicators assessed include teaching materials, benefits for students, contextual material, material summaries and language usage with a score of 3.97 respectively; 4.16; 4.21; 4.26; and 4.11. Meanwhile, for the presentation of teaching materials (Student Valuation Item number 7-18), score 4.15 means that the material developed is already good. The scoring indicators include shape and size, ease of use, color choice, use of lettering, image illustration, material content, teaching materials, and the quality of the techniques with their respective scores. With the result of the score so that the teaching materials product is feasible from the assessment of the student with a record on the condition that the teaching materials are declared worthy if the minimum score calculation is included on the good criteria.

The observation results performed on all three levels of field tests showed that the teaching materials products developed in the test phase were seen to attract students ' interest in reading the teaching materials. After the teaching material is distributed to students, the student is enthusiastic to read the teaching materials. Students ' interest in teaching materials is a good symptom to improve student learning performance. Initially, students felt less interested in African history material because it was considered boring and not contextual. The teaching materials developed here can serve as an alternative source of learning more interesting students compared to reading only grand literature narrative so that through the teaching materials students have alternative sources of learning besides the literature they used 
to use. Of the three stages of the field trials, there was no revised process of developed teaching materials products. During the field trials, there were no significant obstacles, so the revision was carried out. This is a matter of the opinion of (Sugiyono, 2010) that the revision of the product is done when there are shortcomings and weaknesses.

\section{Conclusions}

Based on the results of research and discussion, it can be concluded that the development of African history-based multiculturalism refers to the stage of the Borg and Gall developments grouped into four phases, preliminary studies, Development, field testing, and dissemination of products. Quantitatively developed and qualitative teaching materials are worth using in learning. The feasibility of the teaching material is demonstrated by a material expert assessment of 4.14 which is included in the "good" and media expert assessment of 4.07 which is included in the "good" criteria. While student assessments are limited in field test stages, field tests are wider, and operational tests are respectively 4.19; 4.26; and 4.14. The value 4.19 in field trials are included in the "good" criterion, the 4.26 value in a broader field test is included in the "excellent" criterion, and the 4.14 value in the operational test is included in the "good" criteria. Developed teaching materials can improve student motivation and interest in the study of African history.

\section{References}

[1] Banks, J. (1961). Multicultural Education; Issues and Perspectives. Washington City: Wiley.

[2] Hamid Hasan, S. (2017). Pendidikan Sejarah Untuk Membangun Manusia Baru Indonesia. Jurnal Mimbar Pendidikan, 20(1).

[3] Mbulu Joseph. (2001). Pengajaran Individual. Malang: Yayasan Elang Mas.

[4] Olson, J. (2007). Multiculturalism as a Medium for Promoting Science Literacy. Manchester: Manchester University.

[5] Su'ud, A. (2007). Revitalisasi Pendidikan IPS. Semarang: FIS UNNES.

[6] Sugiyono. (2010). Metode Penelitian Pendidikan. Bandung: Alfabeta.

[7] Suprayogi dkk. (2007). Pendidikan Ilmu Sosial. Semarang: FIS UNNES.

[8] Tatalovic, M. (2009). Science Comics as Tools for Science Education and Communication: Brief, Exploratory Study. Journal of Science Communication, 21(2).

[9] Uno, H. B. (2008). Profesi Kependidikan Problema, Solusi, dan Reformasi Kependidikan di Indonesia. Jakarta: Bumi Aksara. 